\title{
Exploring the Corresponding Words Among the Subgroupings, Revising Swadesh List, Compared with Chinese
}

\author{
Ke Luo \\ Beijing Institute of Spacecraft Environment Engineering, Beijing, China \\ Email address: \\ 1438829559@qq.com \\ To cite this article: \\ Ke Luo. Exploring the Corresponding Words Among the Subgroupings, Revising Swadesh List, Compared with Chinese. International \\ Journal of Language and Linguistics. Vol. 7, No. 3, 2019, pp. 110-118. doi: 10.11648/j.j111.20190703.13
}

Received: March 2, 2019; Accepted: April 29, 2019; Published: May 31, 2019

\begin{abstract}
In 1647, the Dutch linguist Marcus Zuerius van Boxhorn noted the similarity among certain Asian and European languages and first theorized that they were derived from a primitive common language which he called Scythian (proto-language). For hundreds of years, many scholars have been studying the cognate of the subgroupings of Indo-European languages. This paper with the Swadesh list compares several subgroupings of Indo-European languages and finds out that their cognate correspondence is closer. It is inferred that the Proto-Indo-European was a language with very rich vocabulary and should be contained independently in the subgroupings at the beginning of its dissemination. This paper proposes a revised Swadesh list which can be used to assess language homology degree in high or low, and compares English with Chinese. The result shows that Chinese and English have the same origin.
\end{abstract}

Keywords: Indo-European Languages, Swadesh List, English, Chinese, Cognate

\section{Introduction}

The U.S. linguist Morris Swadesh put forward the Swadesh list [1-3] (column English of Table 2) in the middle of 20th century to identify the interrelatedness of languages. The words in the Swadesh list were chosen for their universal, culturally independent availability in as many languages as possible while regardless of their "stability". Swadesh determined by calculation that the change rate of core vocabulary ranged from $14 \%$ to $19 \%$ for every 1000 years [4].

We can further assess the change rate relatedness by Table 1 :

Table 1. Language comparing factors: in different area, in different eras, or been fused by foreign language.

\begin{tabular}{llll}
\hline & eras $_{1}$ & eras $_{2}$ & fusion (eras \\
\hline area $_{1}$ & $\mathrm{~L}_{\mathrm{alel}}$ & $\mathrm{L}_{\mathrm{ale} 2}$ & $\mathrm{~L}_{\mathrm{a} 1 \mathrm{e} 2 \mathrm{f}}$ \\
$\operatorname{rrea}_{2}$ & $\mathrm{~L}_{\mathrm{a} 2 \mathrm{el}}$ & $\mathrm{L}_{\mathrm{a} 2 \mathrm{e} 2}$ & $\mathrm{~L}_{\mathrm{a} 2 \mathrm{e} 2 \mathrm{f}}$ \\
\hline
\end{tabular}

(1) In a area, a language has been used for at least one thousand years without being fused by foreign languages. Then the rate of language change in the two eras: $L_{a 1 e 1}: L_{a 1 e 2}$, should be the lowest, or even not in line with Swadesh conclusion. For example, although Hakka [5] distributed throughout China, have been separated for a thousand of years, they can communicate with each other [6-7] now. It is against Swadesh's views that if more than $10 \%$ of the core vocabulary in the two dialects are different, people will not be able to talk to each other.

(2) In a area with original language, there was at least one kind of foreign language had been fused. The relationship between the two languages is: $\mathrm{L}_{\mathrm{alel}}: \mathrm{L}_{\mathrm{ale} e 2 f}$. For example, Old English/Modern English, Old Chinese/Mandarin Chinese. Swadesh's conclusion of language change rate corresponds to this situation, in line with the "core vocabulary change rate of $14 \%$ to $19 \%$ every 1000 years" [2]. In the so-called millennium, people's tone change may be in a very short time and drastic after language inputted.

(3) A language was inputted into the original language of different areas. A few years later, the divergence between the two languages is: $\mathrm{L}_{\mathrm{a} 1 \mathrm{e} 2 \mathrm{f}}: \mathrm{L}_{\mathrm{a} 2 \mathrm{e} 2 \mathrm{f}}$. For example, the change rate in Italian and French accounts for $23 \%[2]$. The two inputted languages are from the Proto-Indo-European [8]. Language change rate is the highest under this condition.

(4) There's another kind of language comparison. A 
language was spread in two regions at the same time. After several years late, the change rate of the two languages is compared: $\mathrm{L}_{\mathrm{a} 1 \mathrm{e} 2}: \mathrm{L}_{\mathrm{a} 2 \mathrm{e} 2}$. The hypothesis is that the two regions had no language before (in fact, it was not exist). It could be approximated that their original language was very different from the inputted language (non-cognating language). For example, English (or French, etc.) was imported into remote tribes and it became their official language later. This rate of change is currently difficult to be assessed, because the history of world exchanges is not long after all.

At present, it is generally believed that the Indo-European language family [9-10] is derived from a so-called "Proto-Indo-European ", subgroupings: Germanic languages, Romance languages, Celtic group and so on.

What this paper will study is that such as Germanic languages or Romance languages, a few years later, the core vocabulary in the Swadesh list has changed from $14 \%$ to $19 \%$. Although these core words have disappeared in the Swadesh list, do they still remain in their respective languages, and have the original semantics?

\section{Method}

\subsection{Comparing Subgroupings}

According to the core vocabulary of the Swadesh list, we select Greek, Latin and French, with similar pronunciation and same semantics to form Table 2 .

The result shows that the Swadesh list words correspond to 98 (except louse and swim). Several languages have a very high cognate.

Table 2. Comparing the Swadesh list (English) with several subgroupings.

\begin{tabular}{|c|c|c|c|c|}
\hline No. & English & Latin & Greek & France \\
\hline 1 & I & ego & & \\
\hline 2 & you & & Greek: hymeis & French: vous \\
\hline 3 & we & ego & & \\
\hline 4 & this & cis- & & \\
\hline 5 & that & Latin: istud & Greek: tó & \\
\hline 6 & who & qua & & \\
\hline 7 & what & Latin: quod & & \\
\hline 8 & not & Latin: ne "that not" & Greek: ne- "not" & \\
\hline 9 & all & Latin: alius & Greek: allo- & \\
\hline 10 & many & multi- & Greek: mala "very much" & \\
\hline 11 & one & Latin: unus & Greek:-ōnē & \\
\hline 12 & two & Latin: duo & Greek: duo & \\
\hline 13 & big & Latin: būbōn- & bubonic & \\
\hline 14 & long & longus & & \\
\hline 15 & small & & (cf. Greek:) melon & \\
\hline 17 & man & & masculine & \\
\hline 18 & person & Latin: persōna & & \\
\hline 19 & fish & Latin: piscis & & \\
\hline 20 & bird & & & poultry \\
\hline 21 & $\operatorname{dog}$ & & & (e.g. French:) dogue \\
\hline 22 & louse & & & \\
\hline 23 & tree & & Greek: drŷs & \\
\hline 24 & seed & Latin: sēmen & & \\
\hline 25 & leaf & lamina & & \\
\hline 26 & root & radix & & \\
\hline 27 & bark & Latin: barca & & \\
\hline 28 & skin & stratum & & \\
\hline 29 & flesh & Latin: porcus hog, pig & & \\
\hline 30 & blood & & phlebo- & \\
\hline 33 & egg & Latin: ovum & Greek: oon & \\
\hline 34 & horn & & -gon & \\
\hline 35 & tail & Latin: tāliāre & & \\
\hline 36 & feather & ptero- & & \\
\hline 37 & hair & coma & & \\
\hline 38 & head & Latin: caput & & \\
\hline 39 & ear & Latin: auris & & \\
\hline 40 & eye & Latin: oculus & Greek: okkos & \\
\hline 41 & nose & Latin: nasus & & \\
\hline 42 & mouth & cf. Latin: mentum "chin" & & mortise \\
\hline 43 & tooth & Latin: dens & Greek: odontos & \\
\hline 44 & tongue & OldLatin: dingua & & \\
\hline
\end{tabular}




\begin{tabular}{|c|c|c|c|c|}
\hline No. & English & Latin & Greek & France \\
\hline 45 & claw & chela & & \\
\hline 46 & foot & ped- & pod- & \\
\hline 47 & knee & & polygonum (poly- + -gonon) & \\
\hline 48 & hand & & chiro- & \\
\hline 49 & belly & paunch & & \\
\hline 50 & neck & nuchal & & \\
\hline 51 & breasts & pectoral & & \\
\hline 52 & heart & & cardi- & \\
\hline 53 & liver (lobe) & & Greek: liparós (fat) & \\
\hline 54 & drink & Latin: sugere "to suck" & & \\
\hline 55 & eat & Latin: edere "to eat" & & \\
\hline 56 & bite & Latin: findere" to split" & & \\
\hline 57 & see & & scope & \\
\hline 58 & hear & & acoustic & \\
\hline 59 & know & & Greek: *gno- & \\
\hline 60 & sleep & & somnus & \\
\hline 61 & die & & thanato- & \\
\hline 62 & kill & extinguish & & \\
\hline 63 & swim & & & \\
\hline 64 & fly & & & flush \\
\hline 65 & walk & Latin: vadum "ford" & & \\
\hline 66 & come & & & OldFrench: recovrer"come back" \\
\hline 67 & lie & & Greek: lekhesthai "to lie down" & \\
\hline 68 & sit & sedentary & & \\
\hline 69 & stand & Latin: stāre "to stand" & & \\
\hline 70 & give & corban & & \\
\hline 71 & say & & suasion & \\
\hline 72 & sun & solar & & \\
\hline 73 & moon & & Greek: mếnē "moon" & \\
\hline 74 & star & Latin: stella & & \\
\hline 75 & water & aqua & & \\
\hline 76 & rain & Latin: rigare "to wet" & & \\
\hline 77 & stone & saxifrage & & \\
\hline 78 & sand & Latin: sabulum "coarse sand" & & \\
\hline 79 & earth & Africa & & \\
\hline 80 & cloud & cube & & \\
\hline 81 & smoke & & Greek: smykhein "to burn with smolderingflame" & \\
\hline 82 & fire & Greek: pyr & & \\
\hline 83 & ash & MedievalLatin: alkali & & \\
\hline 84 & burn & pyre- & & \\
\hline 85 & path & & & passage \\
\hline 86 & mountain & Latin: montanus & & \\
\hline 87 & red & ruber & & \\
\hline 88 & green & Greek: chlōrós "light green" & & \\
\hline 89 & yellow & icterus & & \\
\hline 90 & white & alb & & \\
\hline 91 & black & flame & & \\
\hline 92 & night & & Greek: nuks "a night" & \\
\hline 93 & hot & ardor & & \\
\hline 94 & cold & gelid & & \\
\hline 95 & full & Latin: plēnus & & \\
\hline 96 & new & & Greek: neos & \\
\hline 97 & good & & & copacetic \\
\hline 98 & round & Latin: rotundus & & \\
\hline 99 & dry & & xero- & \\
\hline 100 & name & & Greek: onoma & \\
\hline
\end{tabular}

\subsection{Comparing Conclusions}

(1) The Proto-Indo-European was a rich language, and the subgroupings (Germanic languages, Roman, Greek, etc.) have a large of corresponding words.

Another example of correspondence, it is generally believed that in 597 AD, the priest St. Augustine of Canterbury [11-12] introduced some Latin words into English, but some corresponding cognate words can also be found in the Germanic languages 
(Table 3).

Table 3. Words from Latin into English to compare words from (or of) Germanic languages.

\begin{tabular}{lll}
\hline No. & words from Latin into English & words from (or of) Germanic languages \\
\hline 1 & creed & glaub \\
2 & pope & father \\
3 & organ & music \\
4 & punch & bore (Proto-Germanic buron) \\
5 & candle & glow \\
6 & shrine & Schrein (German), cognate chaitya (Sanskrit) \\
7 & altar & altāri (Old High German) \\
\hline
\end{tabular}

The etyma of macro- is from Latin, but it has the same cognate with micel "big" (now mickle), as well as terra: chamotte.

Although there are some differences in pronunciation among cognate words, these differences should be adapt to the pronunciation physiological structure of the local people to form a new spelling structure after the fusion of old language.

In the process of rapid dissemination of language, it is difficult for people (non-native speakers) of local area to accurately grasp the tone of the incoming language. For example, American immigrants from the world differ in their pronunciation of English [13]. With the rapid popularization of mandarin in China [14], there are differences in pronunciation among different areas. In turn, it can be inferred that the Proto-Indo-European once had a historical process of rapid dissemination.

(2) Another linguistic phenomenon that exists in the Indo-European language family is that the same semantics has different expressions, namely synonym, such as: all: per-, two: other, big: giant (great) [15]. They all exist in several subgroupings, which shows that the Proto-Indo-European had a variety of expressions for the same semantics.

It can be assumed that the Proto-Indo-European already has had the carrier of character, because only the carrier of character can carry the richness of language expression.

We take advantage of above features to revise the Swadesh list as follows to better reflect the degree of cognate among languages.

\subsection{Revision of the Swadesh List}

The specific approach considered in this paper acknowledges that the Proto-Indo-European was a language rich in synonym, which had been integrated into different subgroupings. Therefore, we keep the original basic Swadesh list (Table 4 grey background items), and add synonyms to the list to define a new list as "Swadesh-synonym-list". These synonyms are no longer confined to the Germanic family. They may come from the ancient Indo-European language family such as Latin and Greek. For example, we add collie (canine) to the corresponding synonym dog, ichthyo- to fish. The results are shown in Table 4.

Table 4. Swadesh-synonym-list [2].

\begin{tabular}{|c|c|c|c|c|c|c|c|c|}
\hline No. & word & value & No. & English & value & No. & word & value \\
\hline 1 & I & 0.6 & 35.1 & rear & 0.4 & 68 & sit & 0.6 \\
\hline 1.1 & self & 0.4 & 36 & feather & 0.6 & 68.1 & akathisia & 0.4 \\
\hline 2 & you & 0.6 & 36.1 & plumage & 0.2 & 69 & stand & 0.6 \\
\hline 2.1 & thee & 0.4 & 36.2 & mane & 0.2 & 69.1 & rear & 0.4 \\
\hline 3 & we & 1 & 37 & hair & 0.6 & 70 & give & 0.6 \\
\hline 4 & this & 0.6 & 37.1 & pilar & 0.2 & 70.1 & furnish & 0.4 \\
\hline 4.1 & here & 0.2 & 37.2 & thrix & 0.2 & 71 & say & 0.6 \\
\hline 4.2 & cis- & 0.2 & 38 & head & 0.6 & 71.1 & phrase & 0.4 \\
\hline 5 & that & 0.6 & 38.1 & top & 0.4 & 72 & sun & 0.6 \\
\hline 5.1 & yon & 0.4 & 39 & ear & 1 & 72.1 & helio- & 0.4 \\
\hline 6 & who & 1 & 40 & eye & 0.6 & 73 & moon & 0.6 \\
\hline 7 & what & 0.6 & 40.1 & mydriasis & 0.4 & 73.1 & seleno- & 0.4 \\
\hline 7.1 & qua & 0.4 & 41 & nose & 0.6 & 74 & star & 0.6 \\
\hline 8 & not & 0.6 & 41.1 & beak (boko) & 0.4 & 74.1 & Etoile & 0.4 \\
\hline 8.1 & un- & 0.4 & 42 & mouth & 0.6 & 75 & water & 0.6 \\
\hline 9.1 & per- & 0.4 & 43 & tooth & 0.6 & 75.2 & hydro- & 0.2 \\
\hline 10 & many & 0.6 & 43.1 & odont- & 0.4 & 76 & rain & 0.6 \\
\hline 10.1 & lot & 0.4 & 44 & tongue & 0.6 & 76.1 & hyeto- & 0.4 \\
\hline 11 & one & 0.6 & 44.1 & sotol & 0.4 & 77 & stone & 0.6 \\
\hline 11.1 & each & 0.4 & 45 & claw & 0.6 & 77.1 & lapis & 0.4 \\
\hline 12 & two & 0.6 & 45.1 & paw & 0.4 & 78 & sand & 0.6 \\
\hline 12.1 & other & 0.4 & 46 & foot & 0.6 & 78.1 & gravel & 0.4 \\
\hline 13 & big & 0.6 & 46.1 & hoof & 0.4 & 79 & earth & 0.6 \\
\hline 13.1 & macro- & 0.2 & 47 & knee & 0.6 & 79.1 & terrene & 0.2 \\
\hline
\end{tabular}




\begin{tabular}{|c|c|c|c|c|c|c|c|c|}
\hline No. & word & value & No. & English & value & No. & word & value \\
\hline 13.2 & giant & 0.2 & 47.1 & patella & 0.4 & 79.2 & soil & 0.2 \\
\hline 14 & long & 0.6 & 48 & hand & 0.6 & 80 & cloud & 0.6 \\
\hline 14.1 & tall & 0.4 & 48.1 & surgeon & 0.4 & 80.1 & rack & 0.2 \\
\hline 15 & small & 0.6 & 49 & belly & 0.6 & 80.2 & nebula & 0.2 \\
\hline 15.1 & wee & 0.4 & 49.1 & tummy & 0.2 & 81 & smoke & 0.6 \\
\hline 16 & woman & 0.6 & 49.2 & stomach & 0.2 & 81.1 & wraith & 0.4 \\
\hline 16.1 & female & 0.4 & 50 & neck & 0.6 & 82 & fire & 0.6 \\
\hline 17 & $\operatorname{man}$ & 0.6 & 50.1 & collar & 0.4 & 82.1 & hot & 0.4 \\
\hline 17.1 & andro- & 0.4 & 51 & breasts & 0.6 & 83 & ash & 0.6 \\
\hline 18 & person & 0.6 & 51.1 & thoraco- & 0.4 & 83.1 & calc- & 0.4 \\
\hline 18.1 & anthropo- & 0.4 & 52 & heart & 0.6 & 84 & burn & 0.6 \\
\hline 19 & fish & 0.6 & 52.1 & cardi- & 0.4 & 84.1 & ether & 0.4 \\
\hline 19.1 & ichthyo- & 0.4 & 53 & liver (lobe) & 0.6 & 85 & path & 0.6 \\
\hline 20 & bird & 0.6 & 53.1 & hepato- & 0.4 & 85.1 & way & 0.4 \\
\hline 20.1 & phoenix & 0.4 & 54 & drink & 0.6 & 86 & mountain & 0.6 \\
\hline 21.1 & collie & 0.4 & 55 & eat & 0.6 & 87 & red & 0.6 \\
\hline 22 & louse & 0.6 & 55.1 & chew & 0.4 & 87.1 & pyrrhotite & 0.4 \\
\hline 22.1 & pediculus & 0.4 & 56 & bite & 0.6 & 88 & green & 0.6 \\
\hline 23 & tree & 0.6 & 56.1 & rodent & 0.4 & 88.1 & chlor- & 0.4 \\
\hline 23.1 & motte & 0.4 & 57 & see & 0.6 & 89 & yellow & 0.6 \\
\hline 24 & seed & 0.6 & 57.1 & watch & 0.2 & 89.1 & blonde & 0.4 \\
\hline 24.1 & hilum & 0.4 & 57.2 & look & 0.2 & 90 & white & 0.6 \\
\hline 25 & leaf & 0.6 & 58 & hear & 0.6 & 90.1 & blanch & 0.4 \\
\hline 25.1 & folio & 0.4 & 58.1 & listen & 0.4 & 91 & black & 0.6 \\
\hline 26 & root & 0.6 & 59 & know & 0.6 & 91.1 & melanin & 0.4 \\
\hline 26.1 & whisker & 0.4 & 59.1 & ware & 0.4 & 92 & night & 0.6 \\
\hline 27 & bark & 0.6 & 60 & sleep & 0.6 & 92.1 & evening & 0.4 \\
\hline 27.1 & rind & 0.4 & 60.1 & doss & 0.4 & 93 & hot & 0.6 \\
\hline 28 & skin & 0.6 & 61 & die & 0.6 & 93.1 & fever & 0.4 \\
\hline 29 & flesh & 0.6 & 62 & kill & 0.6 & 95 & full & 0.6 \\
\hline 29.1 & raw & 0.4 & 62.1 & -cide & 0.4 & 95.1 & plump & 0.4 \\
\hline 30 & blood & 0.6 & 63 & swim & 0.6 & 96 & new & 0.6 \\
\hline 30.1 & sangui- & 0.4 & 63.1 & natant & 0.2 & 96.1 & ceno- & 0.4 \\
\hline 31 & bone & 0.6 & 63.2 & float & 0.2 & 97 & good & 0.6 \\
\hline 31.1 & ossi- & 0.4 & 64 & fly & 0.6 & 97.1 & fine & 0.4 \\
\hline 32 & grease & 0.6 & 64.1 & wing & 0.4 & 98 & round & 0.6 \\
\hline 32.1 & oil & 0.4 & 65 & walk & 0.6 & 98.1 & circle & 0.4 \\
\hline 33 & egg & 0.6 & 65.1 & dromo- & 0.4 & 99 & dry & 0.6 \\
\hline 33.1 & lecithin & 0.4 & 66 & come & 0.6 & 99.1 & arid & 0.4 \\
\hline 34 & horn & 0.6 & 66.1 & fro & 0.4 & 100 & name & 0.6 \\
\hline 34.1 & -gon & 0.4 & 67 & lie & 0.6 & 100.1 & -onym & 0.4 \\
\hline 35 & tail & 0.6 & 67.1 & cubicle & 0.4 & & & \\
\hline
\end{tabular}

With the Swadesh-synonym-list, we can compare two languages (as Table 5). If the Swadesh list comparison method is regarded as "additive principle", that is to add similar words in the corresponding language, then the comparison method of "Swadesh-synonym-list" is the "principle of subtraction", which assumes that the two comparative languages contain corresponding similar pronunciation synonyms. If they can't be found, they should be treated as "missing" items so as to determine the degree of cognate between the two languages. The benefits of doing so are:

(1) It avoids the Swadesh list being judged inaccurately by human factors to affect the evaluation result. For example, the compared with the Swadesh list have been made as many as 118 [16]. The choice of words is mostly based on spoken language, which lacks the consideration of the written language. The use of "Swadesh-synonym-list" can include more relevant words, Needless to think too much about the way of expression or the reasons of the times.

(2) It has a guiding role to directly seek for the similar semantics and pronunciation. It also acknowledges the established historical fact that the comparison is under the premise of the same language family, such as the Sino-Tibetan, Indo-European and Altaic language families, which can further find out the interrelatedness after divergence, the degree of retention of the original words, and the degree of frequency of use, so as to lay a good foundation for subsequent research work.

(3) It can also be used to compare two languages with great differences. If there are two languages in the world, whose origins are absolutely different, and they have not been fused, then we can confirm the complete differences by comparing a large number of synonyms to increase the persuasion of the 
lexicostatistics.

\subsection{The Value of "Swadesh-Synonym-List"}

The items of synonyms in the "Swadesh-synonym-list" may be increased or decreased according to the number of synonyms in the language. A set of mathematical models with statistical significance can be created to assess the cognate. Users may design their own model to increase the list's initiative and flexibility.

In this paper, we define that the score of each semantics of Swadesh-synonym-list is equal to 1 (Table 2), expressed in $\mathrm{S}$, $\mathrm{S}=1$. According to the number of synonyms, the ratio of $\mathrm{S}$ value is allocated (Table 4 ), such as fish: $S=0.6$, ichthyo-: $\mathrm{S}=0.4$; skin: $\mathrm{S}=0.6$, leather: $\mathrm{S}=0.2$; kip: $\mathrm{S}=0.2$.

Ultimately, we need to calculate the overall evaluation value after comparing two languages, which is defined as $R$, called "cognate value".

$$
\mathrm{R}=\sum \mathrm{K}_{\mathrm{i}} * \mathrm{~S}_{\mathrm{i}}(\mathrm{i}=1,2,3, \ldots 100)
$$

In the comparison process, we introduce a weighted coefficient $\mathrm{K}(\mathrm{K}<1)$. $\mathrm{K}$ value reflects the degree of cognate of two compared words. K's value is based on the similarity of pronunciation, the difference of character, and the degree of cognate between the two languages obtained from historical materials and archaeology. If the cognate of the two languages is clear and the correspondence of synonyms is accurate, then $\mathrm{K}=1$.

Next, based on the Swadesh-synonym-list, we will examine the cognate value $\mathrm{R}$ between English and Chinese.

\section{Result}

\subsection{Chinese}

The Chinese Characters was formed at least 3600 years ago [17] (represented by Oracle Bone inscriptions). The development of Chinese is clear. Its historical materials are complete. Its own evolution is slow. The pronunciation of some Chinese words has not changed for thousands of years. Chinese is basically a word with a semantics, a character.

\subsection{K Value and Result}

Because of the monosyllabic characteristics of the Chinese characters, we only compare the initial pronunciation of the "Swadesh-synonym-list" words with the Chinese synonyms to finish Table 5. The value $S$ of each word is shown in Table 4.

The Indo-European language family is alphabetic and multi-syllable. Chinese is from hieroglyphics and it is monosyllable. There is no historical and archaeological data to show that they are cognate. Therefore, the value of weighted coefficient $\mathrm{K}$ should be set lowly, setting $\mathrm{K}=0.4$ (credibility less than $50 \%$ ). If we continue to analyze the historical occurrence times and frequency of each vocabulary, the difference of two languages synonyms correspondence will be greater, and the value of $\mathrm{K}$ will be lower. The corresponding relationship between the final "Swadesh-synonym-list" and Chinese is shown in Table 5.

Comprehensively, According to formula (1), the cognate value R equals 40 .

Table 5. Swadesh-synonym-list compared with Chinese.

\begin{tabular}{|c|c|c|c|c|c|}
\hline No. & English & Chinese & No. & English & Chinese \\
\hline 1 & I & 俺[ăn] & 52 & heart & 怀[huái] \\
\hline 1.1 & self & 私 $[\mathrm{si}]$ & 52.1 & cardi- & 宫[gōng] \\
\hline 2 & you & 汝[rǔ] & 53 & liver (lobe) & 聗[liè] \\
\hline 2.1 & thee & 子 [zǐ] & 53.1 & hepato- & 捍[hàn] \\
\hline 3 & we & 吾[wú] & 54 & drink & 馔[zhuàn] \\
\hline 4 & this & 底[dǐl] & 54.1 & suck & 吮[shǔn] \\
\hline 4.2 & cis- & 斯[sī] & 55.1 & chew & 龃[chú] \\
\hline 5 & that & 搭[dā] & 56 & bite & (齒尃)[bó] \\
\hline 5.1 & yon & 遥[yáo] & 56.1 & rodent & 咬[yăo] \\
\hline 6 & who & 胡[hú] & 57 & see & 视 [shi] \\
\hline 7 & what & 乌 $[w \bar{u}]$ & 57.1 & watch & 望[wàng] \\
\hline 7.1 & qua & 个[gè] & 57.2 & look & 瞭[liào] \\
\hline 8.1 & un- & 无[wú] & 58.1 & listen & 聆 [líng] \\
\hline 9 & all & 完[wán] & 59 & know & 谙[ān] \\
\hline 9.1 & per- & 平[píng] & 59.1 & ware & 悟[wù] \\
\hline 10 & many & 漫沵[màn mǐ] & 60 & sleep & 睡[shuì] \\
\hline 10.1 & lot & 隆[lóng] & 60.1 & doss & 倒[dǎo] \\
\hline 11 & one & 唯[wéi] & 61 & die & 殚[dān] \\
\hline 11.1 & each & $-[\mathrm{y} \overline{1}]$ & 61.1 & moribund & 殁[mò] \\
\hline 12 & two & 陶 [táo] & 61.2 & thanato- & 丧[sàng] \\
\hline 12.1 & other & 二[èr] & 62 & kill & 克[kè] \\
\hline 13 & big & 丕觥[pī gōng] & 62.1 & -cide & 肆[sì] \\
\hline 13.1 & macro- & 茂[mào] & 63 & swim & 水 [shuǐ] \\
\hline 13.2 & giant & 杰[jié] & 63.1 & natant & 阱[nì] \\
\hline
\end{tabular}




\begin{tabular}{|c|c|c|c|c|c|}
\hline No. & English & Chinese & No. & English & Chinese \\
\hline 14 & long & 轮[lún] & 63.2 & float & 浮[fú] \\
\hline 14.1 & tall & 覃[tán] & 64 & fly & 飞[fēi] \\
\hline 15 & small & 小渺[xiăo miăo] & 64.1 & wing & 翁[wēng] \\
\hline 15.1 & wee & 微[wēi] & 65 & walk & 武[wǔ] \\
\hline 16 & woman & 娪[wù] & 65.1 & dromo- & 走[zǒu] \\
\hline 16.1 & female & 妇[fù] & 66 & come & 格[gé] \\
\hline 17 & $\operatorname{man}$ & 孟[mèng] & 66.1 & fro & 复[fü] \\
\hline 17.1 & andro- & 儿[ér] & 67 & lie & 懒[lăn] \\
\hline 18 & person & 匹[p̌̌] & 67.1 & cubicle & 瑟 [guō] \\
\hline 18.1 & anthropo- & 人[rén] & 68 & sit & 席[xí] \\
\hline 19 & fish & 浮[fú] & 68.1 & akathisia & 踠[gui] \\
\hline 19.1 & ichthyo- & 鱼[yú] & 69 & stand & 䟗挺[shì tǐng] \\
\hline 20 & bird & 哺[[bǔ] $]$ & 69.1 & rear & 屹[yì] \\
\hline 20.1 & Phoenix & 凤[fèng] & 70 & give & 给[gěi] \\
\hline 21 & $\operatorname{dog}$ & (盾犬)[dùn] & 70.1 & furnish & 付[fü] \\
\hline 21.1 & collie & 狗[gǒu] & 71 & say & 说 [shui] \\
\hline 22 & louse & (虫虫分)[11̄] & 71.1 & phrase & 赋[fü] \\
\hline 22.1 & pediculus & 螕 $[\mathrm{bī}]$ & 72 & sun & 晛[xiàn] \\
\hline 23 & tree & 楚[chǔ] & 72.1 & helio- & 毁[huǐ] \\
\hline 23.1 & motte & 木[mù] & 73 & moon & 明[míng] \\
\hline 24 & seed & 实[shí] & 73.1 & seleno- & 夕 $[\mathrm{x} \overline{1}]$ \\
\hline 24.1 & hilum & 核[hé] & 74 & star & 星斗[xīng dǒu] \\
\hline 25 & leaf & 绿[lù] & 74.1 & Etoile & 曜[yào] \\
\hline 25.1 & folio & 蒂[fèi] & 75 & water & 窪[wā] \\
\hline 26 & root & 茹[rú] & 75.1 & sero- & 水[shu1̌] \\
\hline 26.1 & whisker & 耏[ér] & 75.2 & hydro- & 沉[hàng] \\
\hline 27 & bark & 朴[pò] & 76 & rain & 润[rùn] \\
\hline 27.1 & rind & 枂[yuè] & 76.1 & hyeto- & 䨡[hán] \\
\hline 28 & skin & 蜕 [shui] & 77 & stone & 石头[shí tóu] \\
\hline 28.1 & leather & 䶻[lú] & 77.1 & lapis & 砾[1i] \\
\hline 28.2 & kip & 革[gé] & 78 & sand & 沙 [shā] \\
\hline 29 & flesh & 膰[fán] & 78.1 & gravel & 砸[gān] \\
\hline 29.1 & raw & 肉[ròu] & 79 & earth & 岸[àn] \\
\hline 30 & blood & 虾膟[pēi lù] & 79.1 & terrene & 地[di] \\
\hline 30.1 & sangui- & 血[xuè] & 79.2 & soil & 垓[gāi] \\
\hline 31 & bone & 髉[bó] & 80 & cloud & 块[kuài] \\
\hline 31.1 & ossi- & 歹[è] & 80.1 & rack & 云[yún] \\
\hline 32 & grease & 膏 [gāo] & 80.2 & nebula & 霓[ní] \\
\hline 32.1 & oil & 膒 $[\overline{0} u]$ & 81 & smoke & 熏冒[xūn mào] \\
\hline 33 & egg & 丸[wán] & 81.1 & wraith & 烟[yān] \\
\hline 33.1 & lecithin & 卵[1uăn] & 82 & fire & 发[fā] \\
\hline 34 & horn & 䚠[hùn] & 82.1 & hot & 火[huǒ] \\
\hline 34.1 & -gon & 觡 [gé] & 83 & ash & 煨[wēi] \\
\hline 35 & tail & 庇[dòu] & 83.1 & calc- & 蛤[gé] \\
\hline 35.1 & rear & 尾[wěi] & 84 & burn & 爆 [bào] \\
\hline 36 & feather & 翡[fěi] & 84.1 & ether & 燃[rán] \\
\hline 36.1 & plumage & 胞[băo] & 85 & path & 阪[băn] \\
\hline 36.2 & mane & 髦[máo] & 85.1 & way & 纬[wěi] \\
\hline 37 & hair & 翰[hàn] & 86 & mountain & 牡[mǔ] \\
\hline 37.1 & pilar & 侲 [biāo] & 86.1 & cordillera & 岗[găng] \\
\hline 37.2 & thrix & 须[xū] & 87 & red & 殷[yān] \\
\hline 38 & head & 首亥[hái] & 87.1 & pyrrhotite & 熛[biāo] \\
\hline 38.1 & top & 头[tóu] & 88 & green & 䌦 [gào] \\
\hline 39 & ear & 耳[ěr] & 88.1 & chlor- & 枯[kū] \\
\hline 40 & eye & 眼[yăn] & 89 & yellow & 熉[yún] \\
\hline 40.1 & mydriasis & 目 [mù] & 89.1 & blonde & 檗[bò] \\
\hline 41 & nose & 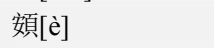 & 90 & white & 纨[wán] \\
\hline 41.1 & beak (boko) & 鼻[bí] & 90.1 & blanch & 白[bái] \\
\hline 42 & mouth & 门[mén] & 91 & black & 鉋[pào] \\
\hline
\end{tabular}




\begin{tabular}{|c|c|c|c|c|c|}
\hline No. & English & Chinese & No. & English & Chinese \\
\hline 42.1 & ostium & 吻[wěn] & 91.1 & melanin & 墨[mò] \\
\hline 43 & tooth & 龆[tiáo] & 92 & night & 暗[àn] \\
\hline 43.1 & odont- & 䶣[ái] & 92.1 & evening & 夜[yè] \\
\hline 44 & tongue & 聑[dān] & 93 & hot & 火[huǒ] \\
\hline 44.1 & sotol & 舌[shé] & 93.1 & fever & 烦[fán] \\
\hline 45 & claw & 跍[gui] & 94 & cold & 况[kuàng] \\
\hline 45.1 & paw & 采[biàn] & 94.1 & algid & 严[yán] \\
\hline 46 & foot & 跗[fū] & 95 & full & 褔[fù] \\
\hline 46.1 & hoof & 觳[hú] & 95.1 & plump & 饱[băo] \\
\hline 47 & knee & 髁扭[kē niǔ] & 96 & new & 婗[ní] \\
\hline 47.1 & patella & 髌[bìn] & 96.1 & ceno- & 新[xīn] \\
\hline 48 & hand & 井[gǒng] & 97 & good & 循[gòu] \\
\hline 48.1 & surgeon & 手[shǒu] & 97.1 & fine & 峰[fēng] \\
\hline 49 & belly & 腹[bì] & 98 & round & 绕[rào] \\
\hline 49.1 & tummy & 肚[dù] & 98.1 & circle & 旋[xuán] \\
\hline 49.2 & stomach & 胘[xián] & 99 & dry & 燥[zào] \\
\hline 50 & neck & (彖頁)[nóu] & 99.1 & arid & 熰 $[\overline{\mathrm{ou}}]$ \\
\hline 50.1 & collar & 颈[gěng] & 100 & name & 娘名[niáng míng] \\
\hline 51 & breasts & 脯[pú] & 100.1 & -onym & 曰名[yuē míng] \\
\hline 51.1 & thoraco- & 胸 [xiōng] & & & \\
\hline
\end{tabular}

\subsection{Cognate Conclusion}

(1) The Indo-European language family and Chinese are cognate. Yan $\mathrm{Fu}$, a Chinese scholar, proposed this as early as 1935 [18]. Many linguists in China are also looking for the basis of cognate and publishing corresponding papers. The cognate of the two languages is reflected not only in the 100 words. We have done a lot of comparative work and got such conclusion.

(2) There are no archaeological, written or even legendary records to illustrate the cognate of the two languages. We believe that $\mathrm{R}=40$, which is a critical small value, belongs to the uncertain relationship. It can be used as a reference value for other language comparison. In the future, more evidence is needed to support it and increase the $\mathrm{K}$ value of the weighting coefficient.

(3) The cognate between the Indo-European language family and Chinese is not only reflected in the pronunciation similarity of vocabulary, but also in the law of language change. For example, the Proto-Indo-European $\mathrm{p}, \mathrm{t}, \mathrm{k}$ become Germanic languages $\mathrm{f}$, th, $\mathrm{h}$ and $\mathrm{b}, \mathrm{d}, \mathrm{g}$ become $\mathrm{p}, \mathrm{t}, \mathrm{k}$ and $\mathrm{f}, \mathrm{th}, \mathrm{h}$ become $\mathrm{b}, \mathrm{d}, \mathrm{g}$. These laws are universality in Chinese.

\section{Conclusion and Discussion}

The language formation can be traced back to 60,000 to 100,000 years ago [19], but the wide spread of language in the world, especially with characters, is a history of 10,000 years [20]. Therefore, a comparative study of languages with cultural backgrounds will be able to better find out the law of language cognate and fusion. Subsequent the refined Swadesh list can be focused on words in different social fields, such as religion, art, tool, thinking, food, clothing, housing and so on, so as to provide more valuable support for the study of language and culture.

The Swadesh list in identifying the interrelatedness of some languages has become a commonly used method. On this basis, this paper proposes the Swadesh-synonym-list to evaluate the interrelatedness between languages with vague cognate. This is an attempt to study language.

\section{References}

[1] Swadesh, Morris. (1950). "Salish Internal Relationships." International Journal of American Linguistics, Vol. 16, 157167.

[2] Swadesh, Morris. (1952). "Lexicostatistic Dating of Prehistoric Ethnic Contacts." Proceedings of the American Philosophical Society, Vol. 96, 452-463.

[3] Holm, Hans J. (2007). "The New Arboretum of Indo-European 'Trees': Can New Algorithms Reveal the Phylogeny and Even Prehistory of Indo-European?" Journal of Quantitative Linguistics, Vol. 14, 167-214.

[4] Swadesh, Morris. (1971). The Origin and Diversification of Language. Ed. post mortem by Joel Sherzer. Chicago. Meier-Brügger, Michael (2003), Indo-European Linguistics, New York: de Gruyter, ISBN 3-11-017433-2.

[5] Luo Meizhen General Dictionary of Hakka Dialect [M] Guangzhou: Sun Yat-sen University Press, 2004.

[6] Kuiper, Koos (P. N) (2017-07-17). The early Dutch sinologists (1854-1900): training in Holland and China, functions in the Netherlands Indies. p. 573. ISBN 9789004339637.

[7] Encyclopædia Britanica (en inglés). 2011. Consultado el 27 de enero de 2013.

[8] Beekes, Robert S. P. (2011). Comparative Indo-European Linguistics: An introduction. Second edition. John Benjamins Publishing. p. 12. ISBN 978-90-272-8500-3.

[9] Quiles, Carlos (June 2017). "Indo-European demic diffusion model" (PDF) (2nd ed.). Badajoz: Universidad de Extremadura. Retrieved March 24, 2018. 
[10] Beekes, Robert S. P. (2011). Comparative Indo-European Linguistics: An introduction. Second edition. John Benjamins Publishing. p. 12. ISBN 978-90-272-8500-3.

[11] Baugh, Albert (1951). A History of the English Language. London: Routledge \& Kegan Paul. pp. 60-83, 110-130 (Scandinavian influence).

[12] Bede (1988). A History of the English Church and People. Sherley-Price, Leo (translator). New York: Penguin Classics. ISBN 978-0-14-044042-3.

[13] Bailey, Guy; Thomas, Erik (1998), "Some aspects of African-American Vernacular English phonology", in Mufwene, Salikoko; Rickford, John R.; Bailey, Guy; Baugh, John, African-American English: Structure, History, and Use, London: Routledge, pp. 85-109.

[14] Rough Guide Phrasebook: Mandarin Chinese. Rough Guides. 2011. p. 19. ISBN 978-1-4053-8884-9.
[15] dictionary https://www.dictionary.com

[16] https://en.m.wiktionary.org/wiki/Appendix:German_Swadesh list

[17] "Carvings may rewrite history of Chinese characters". Xinhua online. 2007-05-18. Retrieved 2007-05-19.; Unknown (2007-05-18). "Chinese writing '8,000 years old"'. BBC News. Retrieved 2007-11-17.

[18] Yan fu. English grammar annotated in Chinese. [M]. Beijing: Business Press, (1933).

[19] Anderson, Stephen (2012). Languages: A Very Short Introduction. Oxford: Oxford University Press. ISBN 978-0-19-959059-9.

[20] Gardiner, Sir Alan H. (1957). Egyptian Grammar: Being an Introduction to the Study of Hieroglyphs, 3rd ed. The Griffith Institute. 